Jurnal Health Sains: p-ISSN: 2723-4339 e-ISSN: 2548-1398

Vol. 2, No. 8, Agustus 2021

\title{
GAMBARAN UMUM FAKTOR RISIKO COVID-19 PADA TENAGA KESEHATAN RUMAH SAKIT DI ASIA
}

\author{
Narizma Nova, Wiku Bakti Bawono Adisasmito \\ Universitas Indonesia (UI) Depok Jawa Barat, Indonesia \\ Email: narizmanova@gmail.com,wiku.adisasmito@gmail.com
}

\begin{tabular}{ll}
\hline INFO ARTIKEL & ABSTRAK \\
\hline Diterima & Pada tahun 2020, hampir 300.000 tenaga kesehatan yang terinfeksi dan \\
5 Agustus 2021 & meninggal akibat Covid-19 di seluruh dunia termasuk Asia. Beberapa \\
Direvisi & negara di Asia termasuk dalam 10 besar kematian tenaga kesehatan \\
15 Agustus 2021 & tertinggi di dunia. Saat angka infeksi dan rawat inap meningkat, tenaga \\
Disetujui & kesehatan harus diprioritaskan agar tidak terkuras oleh infeksi Covid-19. \\
25 Agustus 2021 & Tenaga kesehatan berada pada tingkat risiko tinggi terpapar Covid-19 \\
\hline Kata Kunci: & padahal mereka memegang peran penting dalam penanganan kasus \\
Asia, Covid-19; & Covid-19. Tinjauan sistematis ini bertujuan untuk menganalisis faktor \\
faktor resiko; rumah & risiko tenaga kesehatan di rumah sakit negara-negara Asia terkait Covid- \\
sakit; tenaga & 19. Melalui search engine seperti Science Direct, Springerlink, dan \\
kesehatan & Pubmed, kami mengidentifikasi studi yang relevan dari tahun 2020 \\
& tentang topik faktor risiko penularan Covid-19 di antara petugas \\
& kesehatan di rumah sakit pada negara-negara Asia. Dari pencarian ini, \\
& total 135 makalah diidentifikasi dan 22 studi memenuhi kriteria. Hasil \\
& utama tentang faktor risiko tenaga kesehatan di rumah sakit selama \\
& Covid-19 seperti ketersediaan alat pelindung diri (APD), paparan pasien \\
& yang terinfeksi, beban kerja yang berlebihan, pelatihan PPI, kondisi \\
& medis yang sudah ada sebelumnya dan faktor psikologis. Tingkat \\
& pengetahuan petugas kesehatan tentang Covid-19 tergolong baik, namun \\
& faktor seperti kategori pekerjaan, pengalaman kerja mempengaruhi sikap \\
& dan perilaku mereka sehingga faktor kecemasan, kelelahan dan stres \\
& cukup bervariasi. Dibutuhkan upaya dan strategi yang cukup matang \\
& terutama dari tempat kerja agar faktor risiko dari tenaga kesehatan dapat \\
& diatasi.
\end{tabular}

\begin{abstract}
In 2020, nearly 300,000 health workers who were infected and died due to Covid-19 around the world including Asia. Several countries in Asia are among the top 10 of the highest healthcare workers deaths in the world. When the rate of infection and hospitalization increases, health workers must be prioritized so that they are not drained by the Covid-19 infection. Health workers are at a high risk level for exposure to the Covid-19 while they hold an important roles of handling the Covid-19 case. This systematic review aims to analyze the risk factors of health workers in hospitals among Asian Countries regarding Covid-19. We searched, from Science Direct, Springerlink and Pubmed identify relevant studies from 2020 on the topic of risk factors of transmission Covid-19 among healthcare workers in hospital of Asian Countries. From these searches, a total of 135 papers were identified of which 22 studies met criteria. The main results were about risk factors for health workers in hospitals during Covid-19 such as personal protective
\end{abstract}

$\begin{array}{ll}\text { How to cite: } & \text { Nova, N. \& Adisasmito, W. B. B. (2021) Gambaran Umum Faktor Risiko Covid-19 pada Tenaga } \\ & \text { Kesehatan Rumah Sakit di Asia. Jurnal Health Sains 2(8). https://doi.org/10.46799/jhs.v2i8.258 } \\ \text { E-ISSN: } & 2723-6927 \\ \text { Published by: } & \text { Ridwan Institute }\end{array}$


equipment (PPE) availability, exposure to infected patients, excessive workload, IPC training, pre-existing medical conditions and psychological factors. The level of knowledge of health workers about Covid-19 is classified as good, but factors such as job categories, work

Keywords:

Asia; Covid-19; experience affect their attitudes and behavior so that the factors of healthcare workers; anxiety, fatigue and stress are quite varied. It takes considerable efforts hospital; risk factors and strategies especially from the work place so that the risk factors from health workers can be overcome.

\section{Pendahuluan}

Di awal tahun 2020, dunia dihebohkan dengan munculnya wabah SARS-Cov 2 yaitu Severe Acute Respiratory Syndrome Coronavirus-2 yang berasal dari Wuhan, Provinsi Hubei, China. Pada tanggal 11 Januari 2020, China melaporkan penyebab kematian pertama virus novel corona dan pada tanggal 13 Januari 2020, kasus pertama yang tercatat di luar China, ditemukan di Thailand. Pada akhir bulan Januari, Organisasi Kesehatan Dunia (WHO) mendeklarasikan darurat kesehatan global (Organization, 2018).

Sejak itu, jutaan orang telah terinfeksi dan meninggal karena virus ini. Pada awal September 2020, 27.738.179 kasus terkonfirmasi Covid-19, 899.916 meninggal karena Covid-19 dan hampir 7.000 tenaga kesehatan meninggal karena Covid 19. Menurut Amnesty International (Leslie et al., 2021), sedikitnya 17.000 petugas kesehatan telah meninggal di seluruh dunia karena COVID-19 selama setahun terakhir. Penyebab kematian tenaga kesehatan akibat Covid-19 masih belum dapat dipastikan secara jelas namun ada beberapa asumsi seperti faktor ketidaktahuan pasien yang positif Covid-19, alat pelindung diri (APD) yang buruk, aktivitas sosial di luar tempat kerja, faktor kelelahan/ burnout sampai desain ruang kerja yang tidak memadai.

Hingga saat ini, meski terjadi penurunan kasus Covid-19 karena sebagian besar negara di dunia sudah menerapkan vaksin, namun belum bisa dipastikan kapan pandemi ini akan berakhir. Menurut data statistik di Our World In Data, infeksi baru di seluruh Asia mencapai 146.664 pada akhir Maret 2021 dan angka ini adalah baru pertama yang tertinggi sejak November 2020 . Selain wabah awal pandemi di China, ada 2 puncak lonjakan kasus. di Asia yaitu pada bulan September dan November 2020. Meski negara-negara di Asia telah mencoba berbagai strategi untuk menekan infeksi, pada pertengahan Februari 2021 terjadi gelombang peningkatan lagi ketika ditemukan varian baru, masih adanya pembatasan sosial dan vaksinasi yang berjalan lambat.

Pandemi Covid-19 berdampak besar bagi rumah sakit. Organisasi Rumah Sakit harus menetapkan dan meningkatkan prioritas kesiapsiagaan darurat serta keselamatan tenaga kesehatan (Ferina et al., 2021). Rumah sakit wajib menyediakan lingkungan kerja yang kondusif dan aman bagi mereka. Keselamatan tenaga kesehatan akan mempengaruhi pelayanan kesehatan secara keseluruhan yang akan menentukan tingkat keselamatan pasien. Jika semakin banyak tenaga kesehatan yang terpapar atau meninggal akibat Covid-19 maka beban kerja tenaga kesehatan akan meningkat sehingga kapasitas pelayanan kesehatan dapat menurun dan angka kematian dan kesakitan akan semakin tinggi.

\section{Metode Penelitian}

Penelitian ini dilakukan dengan menggunakan metode systematic review dengan PRISMA-P (Preferred Reposting Items for Systematic review and MetaAnalysis Protocols) sebagai protokol pencarian sesuai dengan flowchart yang telah disusun berdasarkan (Prisma, 2009), sehingga 
untuk menghilangkan artikel yang tidak sesuai melalui identifikasi, penyaringan, dan kriteria inklusi dan eksklusi. Review adalah metode penelitian untuk mengidentifikasi, mengevaluasi, dan menafsirkan semua hasil penelitian yang relevan terkait dengan pertanyaan penelitian tertentu, topik tertentu, atau fenomena yang menjadi perhatian (Kitchenham, 2004). Proses penerapan Systematic Review ini menggunakan search engine yaitu Sciencedirect, Springerlink dan Pubmed. Kata kunci penelitian ini adalah faktor risiko, tenaga kesehatan, rumah sakit, Covid-19 dan Asia. Dengan menggunakan kata kunci tersebut dihasilkan 1.157 artikel, kemudian disaring dan diperoleh 135 artikel. Sebagai kriteria inklusi, pemilihan judul artikel dimulai dari tahun 2020 hingga 2021, format artikel Full PDF, dalam bahasa Inggris dan tidak dipungut biaya. Artikel dengan topik berbeda, hanya abstrak, bukan penelitian dan ulasan, kami hapus dari pencarian. Dari kriteria inklusi dan eksklusi, kami menemukan 22 artikel yang cocok untuk kami review.

\section{Hasil dan Pembahasan}

Dua puluh dua studi tinjauan dilakukan di Cina (10), Singapura (1), Qatar (1), Jepang (1), Iran (2), Arab Saudi (2), Pakistan (2), India (1), Oman (1) dan Asia Selatan (1).

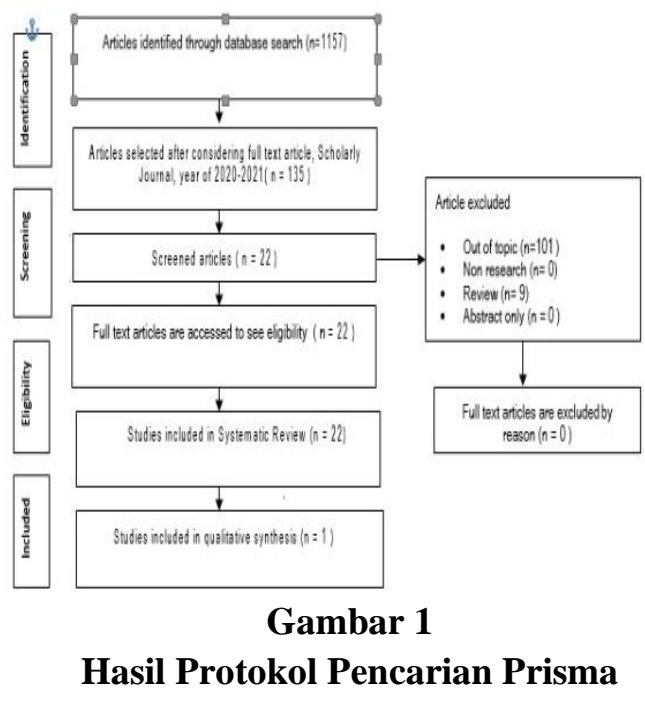

Sebagian besar penelitian ini menggunakan survei cross sectional dan dua penelitian menggunakan studi kohort retrospektif dan studi kualitatif. Jumlah sampel $\pm 4.056 \mathrm{HCW}$ di rumah sakit di negara-negara Asia. 23,9\% laki-laki dan $76,1 \%$ perempuan.

Karakteristik seperti usia, latar belakang pendidikan, status perkawinan, pekerjaan, kategori pekerjaan, komorbid dan tahun pengalaman juga merupakan faktor penting yang dapat mempengaruhi faktor risiko tenaga kesehatan terinfeksi Covid-19.

Tabel 1

Artikel terpilih berdasarkan Protokol PRISMA

\begin{tabular}{|c|c|c|c|c|c|}
\hline No & Judul & $\begin{array}{c}\text { Penulis, Tahun, } \\
\text { Jurnal }\end{array}$ & $\begin{array}{c}\text { Desain } \\
\text { Penelitian }\end{array}$ & Subyek dan Sampel & Hasil \\
\hline 1 & $\begin{array}{l}\text { Risk Factors of Healthcare } \\
\text { Workers With Coronavirus } \\
\text { Disease 2019: A } \\
\text { Retrospective Cohort } \\
\text { Study in a Designated } \\
\text { Hospital of Wuhan in } \\
\text { China }\end{array}$ & $\begin{array}{l}\text { Li Ran et al, } \\
\text { 2020, Journal Of } \\
\text { Hospital } \\
\text { Infection } \\
\text { Issue } 16: 2218- \\
2221\end{array}$ & $\begin{array}{l}\text { Studi } \\
\text { kohort } \\
\text { retrospe } \\
\text { ktif }\end{array}$ & $\begin{array}{ll}\text { Dokter dan } & \text { I } \\
\text { perawat dengan } & 1 \\
\text { gejala } & \text { s } \\
\text { pernapasan akut } \\
\text { di rumah sakit } \\
\text { yang ditunjuk di } \\
\text { Henan, Cina } \\
\end{array}$ & $\begin{array}{l}\text { Departemen yang berisiko tinggi, jam kerja yang lebih } \\
\text { lama, dan kebersihan tangan yang kurang optimal } \\
\text { setelah kontak dengan pasien terkait dengan COVID- } \\
19 \text {. }\end{array}$ \\
\hline 2 & $\begin{array}{l}\text { Knowledge, attitude, and } \\
\text { practice regarding COVID- } \\
19 \text { among healthcare } \\
\text { workers in Henan, China }\end{array}$ & $\begin{array}{l}\text { M Zhang et al, } \\
\text { 2020, Journal Of } \\
\text { Hospital } \\
\text { Infection } 105, \\
\text { 183-187 }\end{array}$ & $\begin{array}{l}\text { Henan, } \\
\text { China } \\
\text { Cross } \\
\text { sectional }\end{array}$ & $\begin{array}{l}1357 \text { tenaga } \\
\text { kesehatan dari } 10 \\
\text { rumah sakit di } \\
\text { Henan, China }\end{array}$ & $\begin{array}{l}\text { 89\% tenaga kesehatan memiliki pengetahuan yang } \\
\text { cukup baik tentang COVID-19, 85\% takut terinfeksi } \\
\text { i dengan virus, dan } 89,7 \% \text { mengikuti praktik yang } \\
\text { benar terkait COVID-19. Beberapa faktor risiko } \\
\text { seperti pengalaman kerja dan kategori pekerjaan } \\
\text { mempengaruhi sikap dan praktik tenaga kesehatan } \\
\text { terkait COVID-19. Untuk melindungi petugas dari } \\
\text { faktor risiko, beberapa tindakan harus diambil yang } \\
\text { terkait dengan kategori pekerjaan, pengalaman kerja, } \\
\text { jam kerja, pencapaian pendidikan, dan petugas garis } \\
\text { depan. }\end{array}$ \\
\hline
\end{tabular}

3 Will healthcare workers Xiauquan Lei, et Cina $1386 \quad$ petugasPerilaku PPI pada departemen berisiko tinggi dan area 


\begin{tabular}{|c|c|c|c|c|}
\hline & $\begin{array}{l}\text { improve infection prevention } \\
\text { and control behaviors as } \\
\text { COVID-19 risk emerges and } \\
\text { increases, in China? }\end{array}$ & $\begin{array}{l}\text { al. 2020, } \\
\text { Antimicrobial } \\
\text { Resistance And } \\
\text { Infection Control, } 9 \\
: 83\end{array}$ & $\begin{array}{l}\text { Cross } \\
\text { sectional }\end{array}$ & $\begin{array}{l}\text { kesehatan pada } 2 \text { yang terkena dampak meningkat dibandingkan dengan } \\
\text { rumah sakit tersierpetugas kesehatan dengan kontak pasien Covid } 19 \text { yang } \\
\text { di Cina } \\
\text { lebih sedikit memiliki perilaku PPI yang lebih buruk. } \\
\text { Kondisi ini mungkin diakibatkan oleh beban kerja yang } \\
\text { lebih tinggi, persediaan dan sumber daya yang tidak } \\
\text { mencukupi di antara tenaga kesehatan. Sistem } \\
\text { kesiapsiagaan harus ditingkatkan dan bantuan medis } \\
\text { sangat dibutuhkan. }\end{array}$ \\
\hline 4 & $\begin{array}{l}\text { Coronavirus Disease } 2019 \\
\text { (COVID-2019) Infection } \\
\text { Among Health Care Workers } \\
\text { and Implications for } \\
\text { Prevention Measures in a } \\
\text { Tertiary Hospital in Wuhan, } \\
\text { China }\end{array}$ & $\begin{array}{l}\text { Xiaouquan Lai, } \\
\text { et al. 2020, } \\
\text { JAMA, Vol 3: } \\
\text { e209687 }\end{array}$ & $\begin{array}{l}\text { Wuhan, } \\
\text { China } \\
\text { Case } \\
\text { series }\end{array}$ & $\begin{array}{lrl}110 & \text { petugas } & \text { Pada penelitian ini menunjukkan bahwa tenaga } \\
\text { kesehatan dengan } & \text { kesehatan non-lini pertama berisiko tinggi } \\
\text { COVID-19 } r \text { di } & \text { terinfeksi selama tahap awal wabah COVID-19, } \\
\text { Rumah } & \text { Sakit } & \text { dan intervensi pada kelompok ini harus dievaluasi. } \\
\text { Tongji dari tanggal } & \text { Sebagian besar tenaga kesehatan yang terinfeksi } \\
\text { 1 Januari hingga } 9 & \text { memiliki gejala ringan. } \\
\text { Februari 2020 } & \end{array}$ \\
\hline
\end{tabular}

\begin{tabular}{|c|c|c|c|c|}
\hline 5 & $\begin{array}{l}\text { What influences the infection Xiaouquan Lai, et } \\
\text { of COVID-19 in healthcare al. 2020, JIDC } 14 \\
\text { workers? } \\
\text { (11):1231-1237 }\end{array}$ & $\begin{array}{l}\text { Wuhan, } \\
\text { China } \\
\text { Cross } \\
\text { sectional }\end{array}$ & $\begin{array}{l}325 \text { tenaga } \\
\text { kesehatan pada } \\
\text { tiga rumah sakit } \\
\text { di Wuhan }\end{array}$ & $\begin{array}{l}\text { Penelitian ini menunjukkan bahwa petugas kesehatan } \\
\text { yang terinfeksi sebagian besar berada di balai } \\
\text { pemeriksaan fisik. Penggunaan APD merupakan faktor } \\
\text { pelindung dalam banyak kasus. Emosi negatif dan } \\
\text { ketidakpuasan terhadap respons rumah sakit dikaitkan } \\
\text { dengan peningkatan risiko infeksi }\end{array}$ \\
\hline 6. & $\begin{array}{l}\text { Burnout and Associated Benjamin Y Q Tan, } \\
\text { Factors Among Health Care et al. 2020, JAMDA } \\
\text { Workers in Singapore During } 21: 1751-1758 \\
\text { the COVID-19 Pandemic }\end{array}$ & $\begin{array}{l}\text { Singapura } \\
\text { Cross } \\
\text { sectional }\end{array}$ & $\begin{array}{l}3075 \text { tenaga } \\
\text { kesehatan di } 4 \\
\text { rumah sakit dan } \\
1 \quad \text { fasilitas } \\
\text { keehatan primer }\end{array}$ & $\begin{array}{l}\text { Studi ini menunjukkan bahwa risiko burnout rentan } \\
\text { terjadi pada setiap tingkat tenaga kesehatan. Faktor } \\
\text { tempat kerja yang dapat dimodifikasi termasuk } \\
\text { pelatihan yang memadai, menghindari shift yang } \\
\text { berkepanjangan lebih dari } 8 \text { jam dan mempromosikan } \\
\text { lingkungan kerja yang aman }\end{array}$ \\
\hline 7. & \begin{tabular}{llr} 
COVID-19 infection among Jameela & Alajmi, \\
healthcare workers in a et.al, & 2020, \\
national healthcare system: The International Journal \\
Qatar experience \\
\multicolumn{2}{c}{ Of Infection Disease } \\
$100: 386-389$
\end{tabular} & $\begin{array}{l}\text { Qatar } \\
\text { Survei } \\
\text { Distributif }\end{array}$ & $\begin{array}{l}16.912 \text { tenaga } \\
\text { kesehatan di } 14 \\
\text { rumah sakit }\end{array}$ & $\begin{array}{l}\text { Hasil penelitian menunjukkan bahwa dari } 16.912 \\
\text { petugas kesehatan yang diperiksa, } 10,6 \% \text { dinyatakan } \\
\text { positif. Di rawat inap } 11,6 \%, 1,3 \% \text { membutuhkan } \\
\text { oksigen tambahan, } 0,6 \% \text { membutuhkan perawatan di } \\
\text { unit perawatan intensif, dan } 0,3 \% \text { membutuhkan } \\
\text { ventilator. Dari survei } 393 \text { tenaga kesehatan, } 5 \% \\
\text { melaporkan tertular infeksi di fasilitas COVID-19 dan } \\
95 \% \text { di fasilitas non-COVID-19 yang mendapatkan } \\
\text { infeksi melalui paparan yang tidak disengaja dari rekan } \\
\text { kerja (45\%) dan pasien ( } 29 \% \text { ). Penularan Covid-19 di } \\
\text { kalangan tenaga kesehatan sering terjadi pada mereka } \\
\text { yang tidak bekerja langsung dengan pasien Covid- } 19 \text {. } \\
\text { Risiko paparan dan kebutuhan akan APD yang ketat } \\
\text { harus ditekankan pada semua petugas kesehatan di } \\
\text { semua tempat }\end{array}$ \\
\hline 8. & $\begin{array}{l}\text { Prevalence of Health Care Takahiro Matsuo, } \\
\text { Worker Burnout During the et.al, 2020, JAMA } \\
\text { Coronavirus Disease 2019 17271 } \\
\text { (COVID-19) Pandemic in } \\
\text { Japan }\end{array}$ & $\begin{array}{l}\text { Tokyo, } \\
\text { Jepang } \\
\text { Cross } \\
\text { sectional }\end{array}$ & $\begin{array}{l}312 \text { tenaga } \\
\text { Kesehatan di } \\
\text { Rumah Sakit } \\
\text { Internasional St. } \\
\text { Luke }\end{array}$ & $\begin{array}{l}\text { Studi ini menunjukkan bahwa lebih dari } 40 \% \text { perawat } \\
\text { dan } 30 \% \text { tenaga radiologi dan apoteker memenuhi } \\
\text { kriteria burnout }\end{array}$ \\
\hline
\end{tabular}

9 The prevalence, characteristics, Qixia Jiang, et. Al, China and related factors of pressure 2020, Int. Wiley $\mathbf{J}$ : injury in medical staff wearing $1-10$ personal protective equipment against Covid-19 in China : A multicenter cross sectional survey

10 Exploring nurses' experiences Nasrin Gahlendar Iran of psychological distress during et.al, 2020, BMC care of patients with COVID- Physciatry $20: 489$ Studi 19: a qualitative study

Studi Cross Cross
sectional 4308 staf medis Prevalensi cedera tekanan akibat perangkat pada staf di 161 rumah medis yang mengenakan APD di Cina sangat tinggi, sakit dan faktor risiko utama yang diidentifikasi adalah berkeringat, jenis kelamin laki-laki, pemakaian APD level 3, dan waktu pakai yang lebih lama.

20 perawat in Studi ini menunjukkan bahwa perawat mengalam rumah sakit banyak tekanan psikologis saat merawat pasien Covidumum 19. Sumber tekanan tersebut terkait dengan kematian pasien, dimensi penyakit yang tidak diketahui, suasana lingkungan kerja, komitmen profesi dan karakteristik individu.

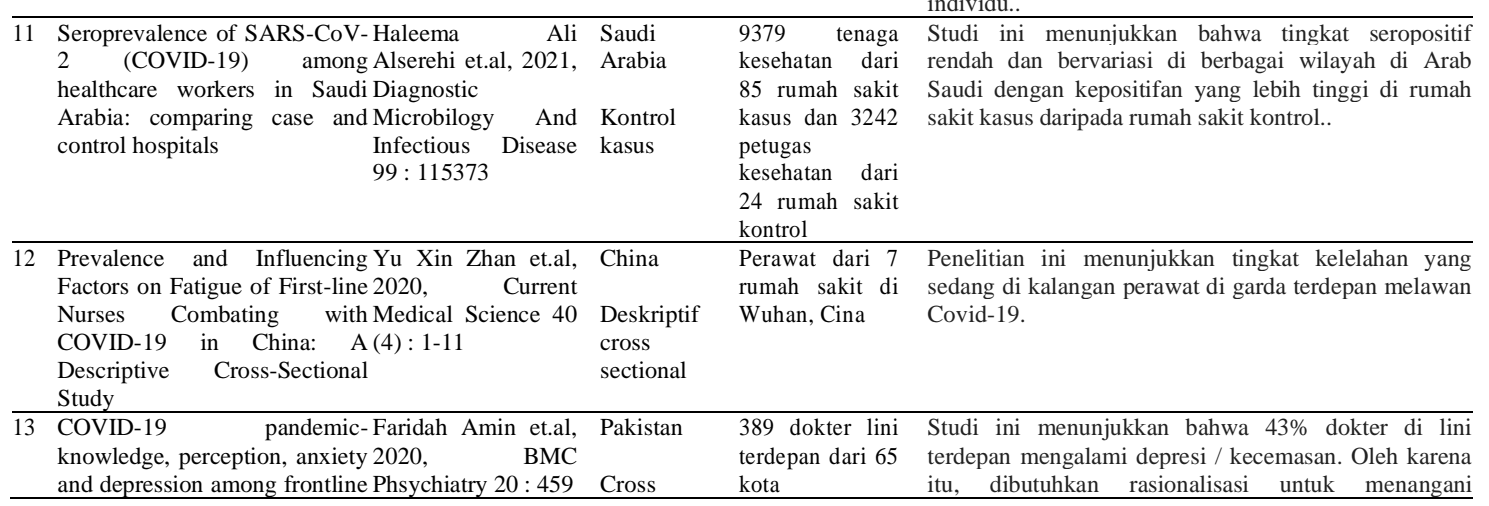




\begin{tabular}{|c|c|c|c|c|}
\hline & doctors of Pakistan & sectionl & & $\begin{array}{l}\text { kesehatan mental dan kesejahteraan dokter yang } \\
\text { merawat pasien selama pandemi ini. }\end{array}$ \\
\hline 14 & $\begin{array}{l}\text { Super-factors associated with Y. Wang et.al, 2020, } \\
\text { transmission of occupational Journal Of Hospital } \\
\text { COVID-19 infection among Infection 106 : 25- } \\
\text { healthcare staff in Wuhan, 34 } \\
\text { China }\end{array}$ & $\begin{array}{l}\text { Wuhan, } \\
\text { China } \\
\text { Cross } \\
\text { sectional }\end{array}$ & $\begin{array}{l}92 \text { tenaga } \\
\text { kesehatan di } \\
\text { Rumah Sakit } \\
\text { Zhongnan } \\
\text { Universitas } \\
\text { Wuhan }\end{array}$ & $\begin{array}{l}\text { Penelitian ini menunjukkan bahwa skor perlindungan } \\
\text { diri yang tinggi menjadi faktor utama yang dapat } \\
\text { mencegah tenaga medis terinfeksi Covid-19 dan faktor } \\
\text { utama penyumbang Covid } 19 \text { adalah menyentuh pipi, } \\
\text { hidung, dan mulut saat bekerja.. }\end{array}$ \\
\hline$\overline{15}$ & $\begin{array}{l}\text { Burnout and its influencing Tahere S.H, et. Al, } \\
\text { factors between frontline } 2020 \text {, Invest. Educ. } \\
\text { nurses and nurses from other Enferm } 38(2) \mathrm{e} 03 \\
\text { wards during the outbreak of } \\
\text { Coronavirus Disease -COVID- } \\
\text { 19- in Iran }\end{array}$ & $\begin{array}{l}\text { Torbat } \\
\text { Heydariya } \\
\mathrm{h} \quad \text { City, } \\
\text { Iran } \\
\text { Cross } \\
\text { sectional }\end{array}$ & $\begin{array}{l}245 \text { perawat lini } \\
\text { depan di target } \\
\text { sasaran rumah } \\
\text { sakit }\end{array}$ & $\begin{array}{l}\text { Hasil penelitian ini menunjukkan bahwa tingkat } \\
\text { burnout perawat di lini depan lebih tinggi dibandingkan } \\
\text { perawat lainnya (p }<0,001) \text {. Faktor yang paling } \\
\text { mempengaruhi adalah stres kerja. }\end{array}$ \\
\hline 16 & $\begin{array}{l}\text { Clinical characteristics and in-Samah I. Abohamr, } \\
\text { hospital outcome of medical et.al, 2020, Saudi } \\
\text { staff infected with COVID-19 Med J Vol } 41 \text { (12) } \\
\text { in Saudi Arabia. A 1336-1343 } \\
\text { retrospective single-center } \\
\text { study }\end{array}$ & $\begin{array}{l}\text { Saudi } \\
\text { Arabia } \\
\text { Cross } \\
\text { sectional }\end{array}$ & $\begin{array}{l}384 \text { staf medis dan } \\
1061 \text { staf non } \\
\text { medis }\end{array}$ & $\begin{array}{l}\text { Hasil penelitian menunjukkan bahwa kejadian Covid- } \\
19 \text { pada tenaga medis cukup tinggi yaitu perawat } \\
58,3 \% \text {, dokter } 34,3 \% \text {, teknisi } 4,6 \% \text { dan apoteker } 2,8 \% \text {. } \\
\text { Kejadian penyakit ekstrim dan kematian sangat rendah } \\
\text { dibandingkan dengan masyarakat umum.. }\end{array}$ \\
\hline
\end{tabular}

\begin{tabular}{|c|c|c|c|c|}
\hline 17 & $\begin{array}{l}\text { Identifying the Risk of SARS-Zhi Gang Song, et. } \\
\text { CoV-2 Infection and Al, 2020, Virologi } \\
\text { Environmental Monitoring in Sinica 35:785-792 } \\
\text { Airborne Infectious Isolation } \\
\text { Rooms (AIIRs) }\end{array}$ & $\begin{array}{l}\text { Shanghai, } \\
\text { Cina }\end{array}$ & $\begin{array}{l}\text { Sampel } \\
\text { lingkungan }\end{array}$ & $\begin{array}{l}\text { Studi ini menunjukkan bahwa dari } 290 \text { tenaga } \\
\text { kesehatan tidak ada yang terinfeksi saat bekerja di AIIR } \\
\text { di rumah sakit. Risiko infeksi dapat dihilangkan dengan } \\
\text { penggunaan penutup alas kaki sekali pakai dan } \\
\text { penerapan langkah-langkah kebersihan lingkungan dan } \\
\text { kebersihan pribadi yang lebih efektif }\end{array}$ \\
\hline 18 & $\begin{array}{l}\text { Assessment of Potential Risk Sugandi Sharma, } \\
\text { Factors for 2019-Novel et.al, 2020, Journal } \\
\text { Coronavirus (2019-nCov) Of Primary Care and } \\
\text { Infection among Health Care Community Health } \\
\text { Workers in a Tertiary Care Vol. 12: 1-7 } \\
\text { Hospital, North India }\end{array}$ & $\begin{array}{l}\text { Wilayah } \\
\text { Persatuan } \\
\text { Chandigar } \\
\text { h di India } \\
\text { Utara }\end{array}$ & $\begin{array}{lr}256 & \text { tenaga } \\
\text { kesehatan } & \text { di } \\
\text { rumah } & \text { sakit } \\
\text { perawatan } & \\
\text { tersier } & \end{array}$ & $\begin{array}{l}\text { Studi ini menunjukkan bahwa dari total } 256 \text { tenaga } \\
\text { kesehatan, } 2 \% \text { dinyatakan positif. Sekitar } 80 \% \text { petugas } \\
\text { kesehatan pernah mengikuti pelatihan PPI. Ditemukan } \\
\text { adanya hubungan yang signifikan secara statistik antara } \\
\text { area penempatan tenaga kesehatan dan keterpaparan } \\
\text { mereka terhadap pasien COVID (durasi paparan, APD } \\
\text { yang dipakai petugas, kontak langsung petugas dengan } \\
\text { materi pasien) dan positif COVID (nilai } P<0,001 \text { ). }\end{array}$ \\
\hline 19 & $\begin{array}{l}\text { COVID-19 Pandemic Raabeeya Said, et.al, } \\
\text { Prevalence and Risk Factors 2021, APJPH 1-5 } \\
\text { for Depression Among Health } \\
\text { Care Workers in South Asia }\end{array}$ & $\begin{array}{l}\text { Pakistan, } \\
\text { India, } \\
\text { Srilanka } \\
\text { Cross } \\
\text { sectional }\end{array}$ & $\begin{array}{l}476 \quad \text { tenaga } \\
\text { kesehatan dari } \\
\text { Pakistan, India } \\
\text { dan Srilanka }\end{array}$ & $\begin{array}{l}\text { Penelitian ini menunjukkan bahwa prevalensi depresi } \\
\text { pada tenaga kesehatan adalah } 25,7 \% \text {. Hampir } 70 \% \text { dari } \\
\text { mereka tidak puas atau sebagian puas dengan APD } \\
\text { yang disediakan. Jenis kelamin perempuan, ketakutan } \\
\text { akan perlindungan, kasus COVID- } 19 \text { yang } \\
\text { dikonfirmasi di tempat kerja dan keluarga ditemukan } \\
\text { sebagai prediktor depresi independen di antara tenaga } \\
\text { kesehatan. Depresi di antara tenaga kesehatan di } \\
\text { negara-negara Asia Selatan cukup berisiko. }\end{array}$ \\
\hline 20 & $\begin{array}{l}\text { Pyschological Impact of Covid- Ming Yu Si, et.al, } \\
19 \text { on medical care workers in } 2020, \quad \text { Infectious } \\
\text { China } \\
\begin{array}{l}\text { Disease Of Poverty } \\
9: 113\end{array}\end{array}$ & $\begin{array}{l}\text { cross } \\
\text { sectional }\end{array}$ & $\begin{array}{l}863 \text { tenaga } \\
\text { kesehatan dari } 7 \\
\text { propinsi di Cina }\end{array}$ & $\begin{array}{l}\text { Studi ini menunjukkan bahwa stres pasca trauma lazim } \\
\text { dan } 40,2 \% \text { positif untuk gejala gangguan stres pasca } \\
\text { trauma yang signifikan. Proporsi memiliki gejala } \\
\text { depresi, kecemasan dan stres ringan hingga sangat berat } \\
\text { masing-masing adalah } 13,6,13,9 \text { dan } 8,6 \% \text { dan perawat } \\
\text { lebih cenderung cemas daripada staf medis lainnya. } \\
\text { Skrining untuk hasil psikologis yang merugikan dan } \\
\text { mengembangkan tindakan pencegahan yang sesuai } \\
\text { akan bermanfaat dalam mengurangi hasil psikologis } \\
\text { negatif. }\end{array}$ \\
\hline 21 & 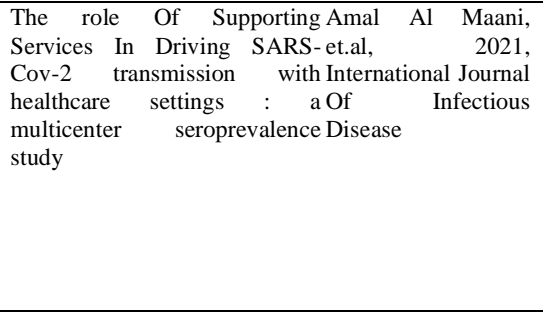 & $\begin{array}{l}\text { Cross } \\
\text { sectional }\end{array}$ & $\begin{array}{lr}1.078 \text { tenaga } \\
\text { kesehatan di } 3 \\
\text { distrik rumah } \\
\text { sakit }\end{array}$ & $\begin{array}{l}\text { Studi ini menunjukkan bahwa dibandingkan dengan } \\
\text { dokter, pekerja dari layanan pendukung, administrasi } \\
\text { dan perawat lebih cenderung memiliki antibodi SARS- } \\
\text { CoV-2 yang positif. Tingkat keseluruhan infeksi yang } \\
\text { sebelumnya tidak terdeteksi adalah } 12 \% \text { dengan nilai } \\
\text { yang lebih tinggi pada petugas kesehatan berisiko } \\
\text { rendah. Prevalensi di distrik yang tinggi merupakan } \\
\text { faktor pendorong seropositif pada kelompok risiko } \\
\text { rendah. Tenaga pelayanan penunjang risiko rendah } \\
\text { dapat mendorong penularan SARS-CoV-2 di rumah } \\
\text { sakit. }\end{array}$ \\
\hline 22 & 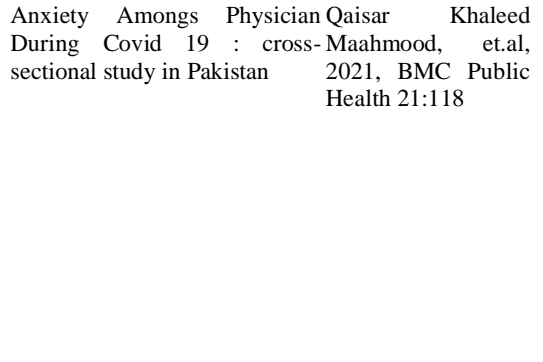 & $\begin{array}{l}\text { Pakistan } \\
\text { Cross } \\
\text { Sectional }\end{array}$ & 103 dokter & $\begin{array}{l}\text { Studi ini menunjukkan bahwa beban kerja yang tinggi } \\
\text { berkontribusi pada kelelahan yang lebih besar dan } \\
\text { ketegangan keluarga yang lebih besar, juga perasaan } \\
\text { terlindungi secara signifikan yang menjelaskan } \\
\text { kecemasan. Mereka mengidentifikasi kebutuhan khusus } \\
\text { dokter untuk peralatan pelindung, kompensasi, } \\
\text { manajemen karantina, alokasi sumber daya, keamanan } \\
\text { dan dukungan publik, peningkatan tata kelola, dan } \\
\text { pengembangan sektor kesehatan. Diperlukan perhatian } \\
\text { untuk mengurangi kecemasan, beban kerja, dan } \\
\text { ketegangan keluarga pada praktisi lini depan yang } \\
\text { merawat pasien Covid dan untuk meningkatkan } \\
\text { perlindungan mereka. }\end{array}$ \\
\hline
\end{tabular}


Dari penelusuran artikel tersebut didapatkan hasil yang dapat dikelompokkan sebagai faktor risiko antara lain APD, perilaku PPI, pengetahuan, praktik dan sikap serta faktor fisiologis. Kepatuhan APD lengkap pribadi lebih tinggi (82\%) di fasilitas Covid 19 dibandingkan dengan fasilitas non Covid 19 (68\%) (Jameela \& Destania, 2020). Penggunaan APD seperti masker efektif, sarung tangan efektif, kaca mata pelindung, baju pelindung, gaun pelindung, penutup sepatu, dan topi $(\mathrm{p}<0,001)$ merupakan faktor protektif infeksi petugas kesehatan saat melakukan operasi umum untuk pasien konfirmasi atau suspek (Lai et al., 2020). Prevalensi DRPI akibat APD di kalangan medis sebesar 30,03\%., dan faktor risikonya adalah berkeringat, laki-laki, memakai APD level 3, dan waktu pakai yang lebih lama (Jiang et al., 2020).

Petugas kesehatan dari departemen berisiko tinggi memiliki praktik pelaporan diri yang lebih baik di sebagian besar perilaku PPI (koeff. Berkisar dari 0,027 hingga 0,149). Petugas kesehatan di daerah yang terkena dampak risiko memiliki kepatuhan yang dilaporkan sendiri lebih tinggi (koeff berkisar antara 0,028 hingga 0,113) dibandingkan dengan petugas kesehatan yang menghubungi pasien yang dicurigai (koefisien bervariasi dari - 0,159 hingga - 0,087) (Lai et al., 2020). Risiko penularan melalui udara di AIIR rendah $(1,62 \%, 25 / 1544)$ karena aliran udara terarah dan prosedur kebersihan lingkungan yang kuat (Song et al., 2020).

Sebanyak $89 \%$ petugas kesehatan memiliki pengetahuan yang cukup, $85 \%$ takut terinfeksi virus sendiri, dan $89,7 \%$ mengikuti praktik yang benar (Guo et al., 2020) Hampir semua dokter memiliki skor pengetahuan sedang hingga tinggi tetapi hanya $12 \%$ dokter yang sepenuhnya puas dengan penyediaan APD dan hampir 94\% merasa tidak terlindungi (Faridah, 2020).
Ambang burnout di Disengagement $79,7 \%$ dan Exhaustion 75,3\%. Skor kecemasan atau depresi etnis Tionghoa atau Melayu 8 , shift yang berlangsung 8 jam, Dipindahkan ke area berisiko tinggi di fasilitas yang berbeda (di luar lokasi) memiliki skor kelelahan yang lebih rendah daripada yang dipekerjakan kembali di dalam fasilitas kerja mereka sendiri (di lokasi) (Tan et al., 2020). Persentase wanita secara signifikan lebih tinggi $(80,6 \%)$, perawat $(46,8 \%)$. Burnout juga lebih umum pada peserta dengan pengalaman yang lebih sedikit, kecemasan yang meningkat karena ketidaktahuan dengan alat pelindung diri, penurunan panjang tidur dengan keinginan untuk mengurangi beban kerja dan keinginan untuk mengharapkan penghargaan atau rasa hormat (Takahiro et al., 2020).

Sebagian besar gejala yang dialami oleh tenaga kesehatan yang tertular adalah Demam $(85,71 \%)$, Batuk $(60,71 \%)$ Sakit Tenggorokan $(15,8 \%)$ Brachypnea $(7,14 \%)$ Dada Distress, Sakit Kepala, Diare, Hemoptisis (7,14\%) adalah beberapa gejalanya. dialami oleh tenaga kesehatan yang terinfeksi Covid-19. Berdasarkan penelitian Samah I., et. al., 2020, Dari 108 petugas kesehatan yang terinfeksi adalah Perawat (58,3\%), Merokok (62\%) dan Diabetes Mellitus (37\%). Petugas kesehatan I8 diisolasi di ICU, Pria (77,8\%), Perokok (88,9\%), Pneumonia (88,9\%). Dari 16.912 Tenaga Kesehatan (Jameela A., et.al, 2929) Positif 10,6\% Rawat Inap 11,6\%, Ventilasi 0,6\% Paparan Infeksi 45\% (kolega) 29\% (pasien). Rasio fatalitas adalah (Kitchenham, 2004) $4,6 \%$. Jenis kelamin laki-laki dengan rasio odds (OR) 7.771 dan riwayat penyakit ginjal kronis (OR 10.778), merupakan prediktor kematian di antara petugas kesehatan (Samah et al., 2020). 


\section{Kesimpulan}

Untuk mengurangi faktor resiko tenaga kesehatan terhadap transmisi infeksi Covid 19, dibutuhkan upaya dan strategi yang cukup besar terutama dari tempat kerja agar faktor risiko ini dapat diatasi. Kesadaran, penyediaan dan penggunaan alat pelindung diri, tata letak departemen dan faktor lingkungan serta manajemen lainnya harus dilengkapi secara ketat. Upaya pemerintah dan dukungan masyarakat juga diperlukan. Yang terpenting adalah dibutuhkan usaha dari kita semua untuk memperbaiki masalah ini.

\section{BIBLIOGRAFI}

Faridah, S. (2020). Strategi Hubungan Masyarakat (Humas) Dalam Meningkatkan Citra Publik Lembaga Pendidikan Pada Masa Pandemic Covid19. Edusiana: Jurnal Manajemen Dan Pendidikan Islam, 7(2), 129-139. Google Scholar

Ferina, F., Isnaeni, B., \& Wulansari, E. M. (2021). Peran Kementerian Kesehatan Dalam Pengendalian Risiko Covid-19 Bagi Tenaga Kesehatan Berdasarkan Peraturan Menteri Kesehatan Nomor 66 Tahun 2016 Tentang Keselamatan Dan Kesehatan Kerja Rumah Sakit. Jurnal Lex Specialis, 2(1). Google Scholar

Guo, Z.-D., Wang, Z.-Y., Zhang, S.-F., Li, X., Li, L., Li, C., Cui, Y., Fu, R.-B., Dong, Y.-Z., \& Chi, X.-Y. (2020). Aerosol And Surface Distribution Of Severe Acute Respiratory Syndrome Coronavirus 2 In Hospital Wards, Wuhan, China, 2020. Emerging Infectious Diseases, 26(7), 1586. Google Scholar

Jameela, I., \& Destania, Y. (2020). Developing Essay Questions On Prism And Pyramid For The Ability To Understand Mathematical Concept. Hipotenusa: Journal Of Mathematical Society, 2(2), 83-97. Google Scholar
Jiang, X., Wu, S., Kuss, M., Kong, Y., Shi, W., Streubel, P. N., Li, T., \& Duan, B. (2020). 3d Printing Of Multilayered Scaffolds For Rotator Cuff Tendon Regeneration. Bioactive Materials, 5(3), 636-643. Google Scholar

Kitchenham, B. (2004). Procedures For Performing Systematic Reviews. Keele, Uk, Keele University, 33(2004), 1-26. Google Scholar

Lai, X., Shu, X., Song, J., \& Xu, H. (2020). Electrophotocatalytic Decarboxylative $\mathrm{C}-\mathrm{H}$ Functionalization $\mathrm{Of}$ Heteroarenes. Angewandte Chemie International Edition, 59(26), 1062610632. Google Scholar

Leslie, D., Mazumder, A., Peppin, A., Wolters, M. K., \& Hagerty, A. (2021). Does "Ai" Stand For Augmenting Inequality In The Era Of Covid-19 Healthcare? Bmj, 372. Google Scholar

Organization, W. H. (2018). Who Expert Consultation On Rabies: Third Report (Vol. 1012). World Health Organization. Google Scholar

Prisma, P. (2009). Guía De Buenas Prácticas, Responsabilidad Social En Las Empresas. España: Fae (Federación Asturiana De Empresarios). Google Scholar

Samah, N. A., Rosli, N. A. M., Manap, A. H. A., Aziz, Y. F. A., \& Yusoff, M. M. (2020). Synthesis \& Characterization Of Ion Imprinted Polymer For Arsenic Removal From Water: A Value Addition To The Groundwater Resources. Chemical Engineering Journal, 394, 124900. Google Scholar

Song, Z., Zou, S., Zhou, W., Huang, Y., Shao, L., Yuan, J., Gou, X., Jin, W., Wang, Z., \& Chen, X. (2020). Clinically Applicable Histopathological Diagnosis System For Gastric Cancer Detection Using Deep Learning. Nature Communications, 11(1), 1-9. Google Scholar 
Takahiro, M., Yasuhiro, H., \& Hideo, A. (2020). Optical Hall Conductivity In Qhe Systems. Google Scholar

Tan, B. Y. Q., Chew, N. W. S., Lee, G. K. H., Jing, M., Goh, Y., Yeo, L. L. L., Zhang, K., Chin, H.-K., Ahmad, A., \& Khan, F.
A. (2020). Psychological Impact Of The Covid-19 Pandemic On Health Care Workers In Singapore. Annals Of Internal Medicine, 173(4), 317-320. Google Scholar

\section{Copyright holder:}

Rositoh, Gita Gloria Oktavia, Vanni Aldioni Putri (2021)

\section{First publication right:}

Jurnal Health Sains

This article is licensed under:

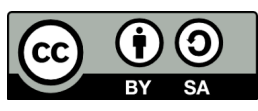

